Miroljub IVANOVIĆ

УДК 37.062-053.6

College of vocational studies for teachers and professional

- стручни рад -

computer scientists - Sirmium, Sremska Mitrovica

Uglješa IVANOVIĆ

Telekom Serbia ltd. Belgrade

\title{
ACADEMIC AND SOCIAL VARIABLES AS PREDICTORS OF PREADOLESCENTS' SCHOOL SATISFACTION
}

\begin{abstract}
The aim of most of the current studies in the field of educational psychology is focused on, apart from the aspects of learning and school success, the emotional and social experiences of adolescents, as well as on their perception of school. The aim of this research was to examine the predictive contribution of academic and social factors (social self-efficiency, perceived academic control, social integration and perceived teacher support) in explaining students' school satisfaction in early adolescence. The research comprised pertinent sample of 230 participants, 120 female and 110 male, from Valjevo, aged 14,52 1 1,38. The following measuring instruments were used: Perceived academic control scale (PAC), Selfefficiency questionnaire for children (SEQ-C), Learning climate questionnaire (LCQ) and The quality of school life (QSL), all of which showed satisfactory internal consistency. The obtained results of nonparametric Pearson correlation coefficient indicated the existence of statistically significant, low and moderate, positive correlation between scores on the scales and questionnaires PAC, SEQ-C, LCQ and QSL $(p<0.01)$. The results of hierarchical regression analysis suggest that academic and social variables explain $61 \%$ of total criterion variance, and individual statistically significant predictors of general school satisfaction are: teacher support, social integration, perceived academic control, social self-efficiency and school success. That revealed that preadolescents with higher scores on those variables also achieve higher scores on school success scale. In addition, this research considers practical and theoretical implication of the obtained results for creating encouraging school environment during the period of early adolescence. The obtained results on students' opinion on their skills can have practical implications and can be useful in diagnosing and planning academic and social determinants, which contribute positively to students' perception of general school satisfaction and relation between curricular and extracurricular activities in Serbia.
\end{abstract}

Key words: self-efficiency, academic control, school life, teacher support, school satisfaction.

\footnotetext{
* Аутор за кореспонденцију: miroljub.ivanovic@ gmail.com
} 


\section{Introduction}

The school perception and satisfaction generally suggest very significant elements of education. Even with the great number of research on the quality and satisfaction with life among adults, studies about students' school satisfaction are quite rare and still insufficiently systematized (Anna-Katharina et al., 2017; Tan , Bradley-Klug \& Chenneville , 2017). The authors (Bear, Yang, Mantz \& Harris, 2017) define the quality of school life as a system of favorable and unfavorable school experiences, and other emotions which correlate with characteristic areas of student' school life. Thus, the subject of quality of school life, apart from general wellbeing of students, also includes emotions linked to specific areas of school life, such as quality of relationships within school environment, relationship with other students and teachers, students' perception on importance of education, sense of school success, as well as learning motivation (Ragnarsdottir et al., 2017). Although, there is a very significant aspect of quality of the educational system in question here, school satisfaction and quality of school life have been rarely explored in the previous researches, and the emphasis has been on consequences instead of causes and factors (Bond et al., 2017).

Looking in general, school satisfaction greatly correlates with students' personal characteristics such as: age, gender, personality dimensions, locus of control (Maghimbi, 2017). In addition to these individual characteristics, selfefficiency and students' attitudes about personal abilities concerning undertaking and realizing activities necessary for achieving prospective goals play significant part (Hanson, 2017). Those convictions of self-efficiency are based primarily on earlier personal experiences or experiences of other, close people (Hanson, Ruff \& Bangert, 2016). The researches (Damian, Stoeber, Negru-Subtirica \& Băban, 2017; Steinhoff \& Buchmann, 2017) point to the connection between self-efficiency, the way to realize various activities, making an effort and persistence in solving difficulties. Despite the fact that self-efficiency can be viewed on a basic level, it is important to emphasize its original task and examine it as a whole within one specific area (Burger \& Samuel, 2017). Social self-efficiency implies a significant type of social skills for functioning in social environment, that is to say person's attitude about their competence to establish social communication and develop new friendships (Martínez-Martí \& Willibald, 2017). That is why social self-efficiency is manifested through social courage, being part of a social group and activities, having close relationships, as well as through offering and receiving help (Hsu, Wiklund \& Richard 2017). Earlier studies have been emphasizing positive correlation between self-efficiency, and useful problem solving and persistence, or negative correlation between lack of confidence and willingness to take responsibility for ending interpersonal conflicts (Terada \& Kawamoto, 2017). In addition, social self-efficiency directly contributes social openness, which further implies basis for creating new ways for interpersonal action, establishing new friendships and maintaining interpersonal relationships. It should also be noted that social self-efficiency correlates with effective social behavior, mental health and higher level of general self-respect (Olenik-Shemesh \& Tali Heiman, 2017). 
Within the range of school, it is necessary to note that students who have more positive attitudes about their social competence, or higher social selfefficiency, usually accomplish academic results and perceive their academic competences in a more positive light (Savage \& Tokunaga, 2017). Additionally, the notion of these perceptions represents academic supervision which reflects students' attitudes about whether they possess certain dimensions of personality that could affect their school performance, or realization of tasks and academic goals (Elliott, Thevenin \& Bigelow, 2017; Karaman \& Watson, 2017). Academic supervision correlates with latent dimension of academic self-efficiency that implies more characteristic opinion of an individual about their own competences essential for efficient learning (Fernandez-Rio, Cecchini, MéndezGimenez, Mendez-Alonso \& Prieto, 2017). With that, the perceived academic supervision and academic self-efficiency greatly contribute students' motivation and their tendency to achieve better grades (Salmela-Aro \& Upadyaya, 2017). Within that context, the perceived academic control positively influences emotional experiences, as students possess higher level of academic control, experience more positive emotions such as pride and general satisfaction, and less negative emotions such as anxiety, disinterest and boredom (Blair \& Raver, 2015). Generally, students' attitudes about their own social and academic competences give relevant contribution to school success and social peer unification (Karabenick \& Zusho, 2015). Students who are not compatible with their peer group, that is, students who are not satisfied with the quality of interrelationships, avoid participating in school activities. Neglected children who do not have identical interests as their peers in school, often feel distanced and less worthy, which to an extent affects their social and emotional development. It is important to add that socially withdrawn students often do not manifest any interest in knowledge functions, which leads to bad school success (Gökmen, 2017).

Apart from relations with students, specific relations between children and teachers who are usually perceived as good people who provide them with knowledge contribute the quality of socialization. It is the teachers' support of students which is the basic factor of positive class atmosphere that has relevant influence on their emotional, social and moral development. Keeping in mind the fact that earlier researches have shown that the mutual positive actions of students and teachers bring to more successful choice of learning strategy and develop positive thinking about personal competences, teachers should not neglect intellectual development and positive working habits of their students (Fraile, Panadero \& Pardo, 2017).

Accepting the results of earlier researches (Gavric, Moscovitch, Rowa \& McCabe, 2017; Houwer, Hughes \& Barnes-Holmes, 2017) about the role of self-efficiency and perceived academic control in the string of behaviors and outcomes, one could conclude that satisfaction with school life should not include solely school accomplishments, but also additional and often neglected factors such as the way children perceive themselves, their academic competences and experiences formed by practice, and their social environment. 
So, earlier studies have tried to shed light from different aspects on the phenomenon of academic and social determinant of general school satisfaction. However, there is a lack of research which would simultaneously examine direction and intensity of relations between various relevant predictors of general school satisfaction. Therefore, the main goal of this research is twofold: (a) prediction of general school satisfaction among adolescents based on predictive values of perceived academic control, social self-efficiency, peer relationship satisfaction, their social unification and teacher relationship satisfaction, and students' perception on whether teachers support their learning and school activities, and (b) examination of the influence of demographic variables - gender and age, on students' school satisfaction. Starting presupposition of the research was that academic and social determinants are significant predictors of general school satisfaction. Since earlier studies have not provided clear and direct answer, gaining better insight into the relations between aforementioned variables is one of the contributions of the research.

\section{Research methodology}

\section{Participants and procedure}

The conducted transversal research included the pertinent sample of 230 participants (120 of female and 110 of male sex), VI and VII grade students of three elementary schools in Valjevo - "Vladika Nikolaj Velimirović", "Desanka Maksimović" and "Milovan Glišić". The average age of the students was 14,52 years $(\mathrm{SD}=1.38)$. The research was conducted in January 2018.

Following the ethical principles of the research, school principals and parents gave their formal consent for student's participation in this testing. Empirical data were acquired anonymously and voluntarily by asking the students to take part in the survey during classes. The size of the group varied from 20 to 30 participants. At the start of the examination, the students were told that the results would be used exclusively for research purposes. Using pen and paper, they were shown the example of the solved task, after which they were asked to cooperate and answer truthfully. They could have quit any time they wanted, without any consequences. It took them approximately 40 minutes to complete the task.

\section{Measuring instruments}

Perceived Academic Control Scale (PAC; Perry et al., 2001) refers to the perceived academic control that represents participants' beliefs about possessing certain constructs such as intelligence, effective cognitive strategy and social skills. The instrument consists of eight items (for example, "The more I try, the better I an in school"). The participant has to evaluate on a 5-point Likert scale ( 1 - I completely disagree; 5 - I completely agree) the level of agreement with each given item. The higher the score, the higher the level of perceived academic control is.

Self-Efficiency Questionnaire for Children (SEQ-C; Muris, 2001) examines the feeling of self-efficiency in three domains: academic, emotional and social. The questionnaire includes 24 items, eight of which refer to social self- 
efficiency, or the behavior which implies perceived ability to realize quality relationship with peers, and assertiveness (for example, "I can easily make friends with other children"). The participant has to evaluate on a 5-point Likert scale ( 1 - completely false; 5 - completely true) to what level the described behavior refers to him. Higher score on this instrument implies higher level of social self-efficiency. Learning Climate Questionnaire (LCQ; Williams \& Deci, 1996)) measures the level of students' perception of learning climate, and which to a certain degree implies their satisfaction with their relationship with teachers. The shortened version of this questionnaire was used - a 7-point scale (for example, "I feel that teachers do not understand me") where students evaluate their agreement with the six given items ( 1 - I completely disagree, 7 - I completely agree). The higher score on the questionnaire means better learning climate, that is, greater satisfaction with relationship with teachers.

The Quality of School Life Questionnaire (QSL; Ainley \& Bourke, 1992) consists of 40 items, and a 7-point scale, which examines various aspects of quality of school life satisfaction. Only two scales were used in this research: General school satisfaction scale (for example, "For me, school is a place where I like going every day"), which contains 6 items and measures total students' school satisfaction, and Social integration scale (for example, "For me, school is a place where I am popular among peers"), which measures students' satisfaction with peer relationship. The participant's task is to express the level of agreement with the content of every individual item on the 4-point scale (1 - I completely disagree, 4 - I completely agree). The higher the result on the scales, the higher level of school satisfaction, that is, satisfaction with peer relationship is.

\section{Data processing}

Descriptive and inferential statistical techniques were used for data processing and statistical analysis. Firstly, the method of descriptive statistics AM (arithmetic mean), SD (standard deviation) and reference range (minimal and maximum values) were used. Cronbach's alpha coefficient was used to evaluate internal consistency of the measuring instruments. Perason's parametric correlation coefficient was used to determine the level of linear correlation between the observed variables, while the hierarchical regression analysis determined the contribution of predictors to criterion variable. With hypotheses testing, p-values lower than 0,05 were considered statistically significant. Software package SPSS for Windows 12.0 was used for statistical data analysis.

\section{Research results}

As it is shown in Table 1., here are presented basic descriptive indicators and coefficients of internal consistency for the applied measuring instruments. The obtained Cronbach's alpha coefficients point to satisfactory consistency of questionnaires and the total reference range point to satisfactory variable sensitivity, when it comes to domestic population. 
Table 1. Descriptive parameters and instrument reliability

\begin{tabular}{|l|c|c|c|c|c|}
\hline Variables & AM & SD & Min & Max & $\boldsymbol{\alpha}$ \\
\hline Social self-efficiency & 29.15 & 5.92 & 10 & 46 & 0.80 \\
\hline Perceived academic control & 27.34 & 5.98 & 8 & 39 & 0.81 \\
\hline Social integration & 14.97 & 2.68 & 7 & 19 & 0.76 \\
\hline Learning climate & 27.44 & 9.03 & 7 & 39 & 0.84 \\
\hline General school satisfaction & 12.90 & 4.55 & 7 & 25 & 0.88 \\
\hline
\end{tabular}

Legend. $A M$ - arithmetic mean, $S D$ - standard deviation, Min - minimal value,

Max - maximum value, $\alpha$-Cronbach's alpha coefficient.

Table 2 displays the values of parametric Pearson correlation coefficient of the variables which examine the level of linear correlation of school success, social self-efficiency, perceived academic control, social integration and learning climate and general school satisfaction.

Table 2. Intercorrelations between the examined variables

\begin{tabular}{|c|c|c|c|c|c|c|c|c|}
\hline Variables & $v \mathbf{1}$ & $v \mathbf{2}$ & $v \mathbf{3}$ & $v \mathbf{4}$ & $v \mathbf{5}$ & $v \mathbf{6}$ & $v \mathbf{7}$ & $v \mathbf{8}$ \\
\hline $\begin{array}{c}\text { 1. social self-effici- } \\
\text { ency (v1) }\end{array}$ & - & $0.39 * *$ & $0.52 * *$ & $0.19 * *$ & $0.20 * *$ & 0.09 & 0.05 & -0.01 \\
\hline $\begin{array}{c}\text { 2. academic control } \\
(v 2)\end{array}$ & & - & $0.29 * *$ & $0.40 * *$ & $0.32 * *$ & $0.43 * *$ & 0.09 & $-0.15 *$ \\
\hline $\begin{array}{c}\text { 3. Social integration } \\
(v 3)\end{array}$ & & - & $0.29 * *$ & $0.38 * *$ & 0.01 & -0.06 & -0.09 \\
\hline $\begin{array}{c}\text { 4. Learning climate } \\
(v 4)\end{array}$ & & & - & $0.47 * *$ & -0.04 & -0.08 & $-0.16 *$ \\
\hline $\begin{array}{c}\text { 5. General school } \\
\text { satisfaction (v5) }\end{array}$ & & & & - & -0.03 & -0.07 & $-0.17 *$ \\
\hline $\begin{array}{c}\text { 6. School success } \\
(v 6)\end{array}$ & & & & & & $0.33 * *$ & -0.05 \\
\hline $\begin{array}{c}\text { 7. Gender } \\
(v 7)\end{array}$ & & & & & & & 0.02 \\
\hline $\begin{array}{c}\text { 8. Age/grade } \\
(v 5)\end{array}$ & & & & & & & - \\
\hline
\end{tabular}

Annotation. $* p<.05 ; * * p<.01$.

The results of correlation analysis point to statistically relevant and positive correlations between the used variables. Maximum bivariate correlation of moderate intensity was manifested between the variable scores of social selfefficiency and social integration $(r=0.52, p<0.01)$, and minimal low intensity was manifested between variable scores of perceived academic control and age/gender $(r=-0.15, p<0.05)$. Four individual series of hierarchical regression analysis were applied with the aim of examining individual contribution of self-evaluated academic control and social self-efficiency, as well as social integration and learning climate in predicting general school satisfaction as criterion/dependent variable (Table 3). 
Table 3. The results of hierarchical regression analysis of predicting general school satisfaction based on academic and social determinants

\begin{tabular}{|l|c|c|c|c|}
\hline Predictors & $\begin{array}{c}\text { 1. step } \\
\text { (model) } \beta\end{array}$ & $\begin{array}{c}\text { 2. step } \\
\text { (model) } \beta\end{array}$ & $\begin{array}{c}\text { 3. step } \\
\text { (model) } \beta\end{array}$ & $\begin{array}{c}\text { 4. step } \\
\text { (model) } \beta\end{array}$ \\
\hline Gender & 0.05 & 0.02 & 0.04 & 0.03 \\
\hline Grade & -0.01 & -0.04 & 0.06 & 0.01 \\
\hline School success & -0.08 & -0.06 & 0.20 & 0.14 \\
\hline Social self-efficiency & & 0.21 & 0.01 & 0.02 \\
\hline Perceived academic control & & & 0.29 & 0.16 \\
\hline Social integration & & & & 0.31 \\
\hline Learning climate & & & & 0.38 \\
\hline$R$ & 0.02 & 0.21 & 0.29 & 0.62 \\
\hline$R^{2}$ & 0.05 & 0.03 & 0.09 & 0.61 \\
\hline$\Delta R^{2}$ & - & 0.03 & 0.11 & 0.19 \\
\hline
\end{tabular}

Legend. $\beta=$ The value of standardized regression coefficient; $R=$ multiple correlation coefficient; $R^{2}=$ total contribution of predictors in explained variance; $\Delta R^{2}=$ change of the coefficient of multiple determination; ${ }^{*} p \leq .05,{ }^{*} p \leq 0.01$.

In all regression analyses, the total of the seven variables chosen was introduced in four steps. Step 1 (model 1) of the analysis included the group of three control predictor variables: gender and grade as covariates and school success. Then, in step 2 (model 2), social self-efficiency was introduced, and perceived academic control was introduced in the next step (model 3). The final step (model 4) of the multiple regression equation included two potential independent variables: social integration and perceived learning climate.

It turned out that control predictor variables from step 1. did not explain the variance $(2 \%)$ of school satisfaction, while after the second step of the analysis and based on the control variables (gender, grade and school success) relatively little has been explained, only $3 \%$ of the variance, where social selfefficiency $(\beta=0.29)$ proved statistically significant predictor of school satisfaction. But in 3. step of regression equation, after introducing perceived academic control $(\beta=0.29)$, the percentage of the explained criterion variability increased significantly to $11 \%$, and thus the predictor of social self-efficiency lost its previous statistical significance. Finally, following significant individual predictors of general school satisfaction, apart from perceived academic control $(\beta=0.16)$ the significance of which has been determined in the 3. step of the analysis, were introduced in the last 4 . step of the analysis as the additional predictors of the final regression model - social integration $(\beta=.31)$, learning climate $(\beta=$ 0.38 ) and school success $(\beta=0.14)$, which increased the variance percentage to $19 \%$. So the obtained positive signs of the standard regression coefficient revealed that preadolescents are more satisfied with school if they are more satisfied with school life and peer relationship, if they have quality relationship with peers and they have teacher support, and therefore greater intelligence and social skills and school success. Also it is important to add that first type linear 
correlations did not manifest correlation between school success and school satisfaction, and that would mean that the contribution of school success was probably the result of suppressor effect!

Finally, the finished regression equation revealed that the examined group of statistically significant predictor variables explained $61 \%$ of total criterion variance. Consequently, the obtained, significant beta-coefficients of school success, social self-efficiency, perceived academic control, social integration and learning climate all have relatively good predictive value, but clearly there are other unexplored factors which would help achieve more exact prediction of the criterion of school satisfaction.

\section{Discussion}

This paper included twofold examination of 1) predictive values of individual predictor variables of preadolescents - their own academic and social competences and their social integration, as well as the perception of supportive learning climate on students' general school satisfaction and 2) age, gender and school success on students' school satisfaction. Current researches have shown that each $\mathrm{f}$ these variables has partial contribution to school satisfaction. However, there is a lack of studies which would broadly explore relations of individual influence of relevant variables on school satisfaction.

The findings of this research have shown correlation between school success and self-evaluated academic control, which matches the earlier researches on the relevant role of student belief about own competences, skills and knowledge which could influence general school satisfaction (Burger \& Samuel, 2017; Idrus $\&$ Salleh, 2017). Precisely belief in self-efficiency and perception of control contribute school success, making an effort and dedication to school activities, which brings more success. At the same time, the results of this research point to the importance of students' school success, which is in accordance with the findings of the study that determined the complex relations between students' belief about own competences and school success (Fuller, Powell \& Fox, 2017). Actually, the greatest number of earlier studies puts an emphasis on the point that students who have better school success and generally more satisfied with school (Miller, Ramirez \& Murdock, 2017; Oga-Baldwin, \& Nakata, 2017; Raufelder, Bakadorova, Yalcin, Dibek \& Yavuz, 2017). However, it is necessary to note that relations between school success and school satisfaction are not easy to comprehend and are generally accomplished by considering students' belief about own academic competences, which represent the possibility of overseeing academic success (Bear, Yang, Mantz \& Harris, 2017).

The findings of this research revealed that even though the relationship between the examined variables of school success and general school satisfaction is not present in the intercorrelational matrix, in the regression matrix school success has proven itself to be negative predictor of school satisfaction, which points to the suppression effect between aforementioned variables. The obtained results are in accordance with previous research (Wilkerson, Pérusse \& 
Hughes, 2013), which makes further conclusion about the positive influence of perceived academic control on school success. In addition, it is important to emphasize that students' academic perceptions are significant for their school satisfaction. Likewise, it is important to emphasize that students' academic perceptions are significant not only for their school satisfaction but also for general life satisfaction which has a relevant influence on their school success and competences (Sammons, Davies, Day \& Gu, 2014). Certainly, it is significant to add that this correlation clearly depends on the specifics of various school systems and cultures, that is, on the methods of valorization of school success and the significance appointed to academic success that differs significantly from state to state and which influences the share these variables have in school success among preadolescent (Berkowitz et al., 2015).

Apart from school success and perceived academic control, the findings of the conducted research revealed social integration as significant determinant of school satisfaction, which indicates that there is a lack of quality peer relationships which is significant determinant of school dissatisfaction, seeing how quality peer relationship contributes satisfactory school perception (Agans, Champine, Johnson, Erickson \& Yalin, 2015). To add, current studies point out that satisfaction with social relations correlates to both school satisfaction and general life satisfaction (Moksnes, Løhre, Lillefjell, Byrne \& Haugan, 2014). These findings are not surprising since the need for closeness represents basic human need for accomplishing a goal, that is realized through peer relations and that greatly improves the quality of life (Larson \& Tran, 2014). Successful peer relations correlate positively with general life satisfaction, general self-efficiency, emotional wellbeing and social behavior, and they correlate negatively with depression and certain negative emotional states (Evans \& Cassells, 2014). Although these correlations refer to certain people in all stages of life, the significance of social integration and mutual influence on peers is particularly important during the period of preadolescence (Kimiecik \& Horn, 2014). That is in accordance with the results of this research, and shows the significance of social link between students and general school satisfaction.

Besides, the obtained results have shown that the share of social integration influences general school satisfaction through preadolescents' academic control. That means that bringing optimal social relations with peers on a higher level is not necessary for the increase of school satisfaction among the students who believe they cannot oversee their own perceived academic success. However, the high level of school satisfaction can be easily realized by preadolescents who are effectively integrated in class, which helps them form favorable opinion about their own competences necessary for school success. Moreover, they can also be partly predicted through intensive correlation between students' academic and social experiences. With that in mind, it is necessary to stress that school success correlates with socio-emotional sates of preadolescents which influence their behavior, social status and attitudes towards peer communication. In that way, the relevant match of academic and social problems and goals exists within school environment, because school success and academic success correlate with social integration and individual opinion about own social competences (Martin \& Steinbeck, 2017). 
While presenting the obtained results, it is necessary to take into account several factors which limit the generalization of the results. First of all, the correlational design of this research offers limited possibility of making a conclusion about causal link between the measured variables. Then, the data obtained in this research reveal the self-evaluations of participants who generally include shortcomings, such as the problem of dividing the variability and cultural specificity. Therefore, further research needs to include additional data sources on representative sample, and conduct longitudinal research with long-term effect of the examined variables on preadolescents' success and satisfaction, as well as include other relevant predictor variables such as emotional skills and goal of school success.

However, despite the aforementioned shortcomings, the findings of this research are informative for teachers since they point to the complex interactions of academic and social factors in school environment which in the long run affect students' adaptation and perception, as well as their mental health and school success (Ragnarsdottir, et al., 2017). At the same time, it is necessary to keep in mind the relevant influence teachers have on students who appreciate their support. Increased awareness about that factor can have positive effect and can most likely redeem students' problems since studies have showen that their beliefs about own competences and school accomplishments can be changed with minimal effort (Lopes, Santos, Mota, Pereira \& 2017). Further research on this subject is going to be quite significant because of the still insufficiently examined predictors of school satisfaction and satisfaction with the quality of school life, despite their relevance for cognitive, emotional and social development of preadolescents. The findings of this research also reveal that social and academic factors have important function in examining the quality of school life, and therefore students' school satisfaction has to be analyzed together with school environment and the ways in which students self-evaluate their academic and social skills.

Theoretical analysis and the conducted research help pedagogical psychology and pedagogical practice to discover academic and social factors which would enable conducting various programs and preventive activities in order to increase school satisfaction and present guidelines to improving and modernizing educative work.

The practical implications of this research primarily refer to the need for early identification of academic and social constructs of preadolescents. By conducting various programs and preventive activities, their school satisfaction would increase. In methodological sense, one should keep in mind the great importance of demographic variables (gender and age) which could influence school satisfaction among students in the period of early adolescence. 


\section{References}

1. Agans, J., Champine, R., Johnson, S., Erickson, K., \& Yalin, C. (2015). Promoting healthy lifestyles through youth activity participation: Lessons from research. In E. Bowers, J. Geldhof, S. Johnson, L. Hilliard, R. Hershberg, J. Lerner, $\&$ R. Lerner (Eds.), Promoting positive youth development: Lessons from the 4H study (pp. 137-159). New York, NY: Springer.

2. Ainley, J., \& Bourke, S. F. (1992). Student views of primary schooling. Research Papers in Education, 7(2), 107-128.

3. Anna-Katharina, P., Lauermann, F., Klassen, R. M., Dickhäuser, O., Janke, S., $\&$ Dresel, M. (2017). Longitudinal relations between teaching-related motivations and student-reported teaching quality. Teaching and Teacher Education, 65, 241-254.

4. Archambault School of Psychoeducation, School Environment Research Group, Université de Montréal Public Health Research Institute, Université de Montréal, Montréal, Quebec, Canada, I., \& Dupéré, V. (2017). Joint trajectories of behavioral, affective, and cognitive engagement in elementary school. The Journal of Educational Research, 110(2), 188-198.

5. Bear, G. G., Yang, C., Mantz, L. S., \& Harris, A. B. (2017). School-wide practices associated with school climate in elementary, middle, and high schools. Teaching and Teacher Education, 63, 372-383.

6. Berkowitz, R., Glickman, H., Benbenishty, R., Ben-Artzi, E., Raz, T., Lipshtadt, N., et al. (2015). Compensating, mediating, and moderating effects of school climate on academic achievement gaps in Israel. Teachers College Record, 117, 1-34.

7. Blair, C., \& Raver, C. C. (2015). School readiness and self-regulation: a developmental psychobiological approach. Annu. Rev. Psychol. 66, 711-731.

8. Bond, L., Butler, H., Thomas, L., Carlin, J., Glover, S., Bowes, G., et al. (2017). Social and School Connectedness in Early Secondary School as Predictors of Late Teenage Substance Use, Mental Health, and Academic Outcomes. Journal of Adolescent Health, 40 (4), 357-364.

9. Burger, K \& Samuel, R. (2017). The Role of Perceived Stress and Self-Efficacy in Young People's Life Satisfaction: A Longitudinal Study. Journal of Youth and Adolescence, 46(1),78-90.

10.Elliott Colorado State University, Fort Collins, Colorado, USA, J. W., Thevenin Colorado State University, Fort Collins, Colorado, USA, M. K., \& Bigelow Texas A\&M University, College Station, Texas, USA, B. F. (2017). Promoting CM Student Success: Establishing an Academic Performance Benchmark Given Construction-Education Self-Efficacy, Motivation and Planned Behavior. International Journal of Construction Education and Research, 34, 1-15.

11.Evans, G. W., \& Cassells, R, C. (2014). Childhood Poverty, Cumulative Risk Exposure, and Mental Health in Emerging Adults. Clinical Psychological Science, 2, 287-296.

12.Fernandez-Rio, J., Cecchini, J. A., Méndez-Gimenez, A., Mendez-Alonso, D., \& Prieto, J. A. (2017). Self-Regulation, Cooperative Learning, and Academic SelfEfficacy: Interactions to Prevent School Failure. Front Psychol 8(22), 1-7. 
13. Fraile, J., Panadero, E., \& Pardo, R. (2017). Co-creating rubrics: The effects on self-regulated learning, self-efficacy and performance of establishing assessment criteria with students. Studies in Educational Evaluation, 53, 69-76.

14.Fuller, C., Powell, D., \& Fox, S. (2017). Making gains: the impact of outdoor residential experiences on students' examination grades and self-efficacy. Educational Review, 69 (2), 232-247.

15.Gavric, D., Moscovitch, D. A., Rowa, K., \& McCabe, R. E. (2017). Post-event processing in social anxiety disorder: Examining the mediating roles of positive metacognitive beliefs and perceptions of performance. Behaviour Research and Therapy, 91, 1-12.

16. Gökmen, A. (2017). Psychological maltreatment, coping strategies, and mental health problems: A brief and effective measure of psychological maltreatment in adolescents. Child Abuse \& Neglect, 68, 96-106.

17. Hanson, J. (2017). Testing the Difference between School Level and Academic Mindset in the Classroom: Implications for Developing Student Psycho-Social Skills in Secondary School Classrooms. Journal of Educational Issues, 3(1), 44-63.

18. Hanson, J., Ruff, W., \& Bangert, A. (2016). Investigating the Relationship between School Level and a School Growth Mindset. Journal of Educational Issues, 2(2), 203-221.

19.Houwer, J. D., Hughes, S., \& Barnes-Holmes, D. (2017). Psychological Engineering: A Functional-Cognitive Perspective on Applied Psychology. Journal of Applied Research in Memory and Cognition, 6(1), 1-13.

20.Hsu, D. K., Wiklund, J., \& Richard G. H. (2017). Success, Failure, and Entrepreneurial Reentry: An Experimental Assessment of the Veracity of Self-Efficacy and Prospect Theory. Entrepreneurship Theory and Practice, 41(1), 19-47.

21. Xu, Z., \& Jang, E. E. (2017). The role of math self-efficacy in the structural model of extracurricular technology-related activities and junior elementary school students' mathematics ability. Computers in Human Behavior, 68, 547-555.

22.Idrus, H., \& Salleh, R. (2008). Perceives self-efficacy of Malaysian ESL Engineering and technology students on their speaking ability and its pedagogical implications. The English Teacher, 37, 61-75.

23. Karaman, M. A., \& Watson, J. C. (2017). Examining associations among achievement motivation, locus of control, academic stress, and life satisfaction: A comparison of U.S. and international undergraduate students. Personality and Individual Differences, 111(1), 106-110.

24. Karabenick, S. A., \& Zusho A. (2015). Examining approaches to research on self-regulated learning: conceptual and methodological considerations. Metacogn. Learn.10, 151-163.

25. Kimiecik Miami University, J. C., \& Horn Miami University, T. S. (2014). The big motivational picture: Examining the relationship between positive intrapersonal processes and adolescent health-promoting behaviors. Applied Developmental Science, 21(1), 42-57.

26.Larson, R., \& Tran, S. (2014). Invited commentary: Positive youth development and human complexity. Journal of Youth and Adolescence, 43, 1012-1017.

27.Lopes, L., Santos, R., Mota, J., Pereira, B., \& Lopes, V. (2017) Objectively measured sedentary time and academic achievement in schoolchildren, Journal of Sports Sciences, 35, 5, 463-469. 
28. Maghimbi, S. (2017). The Quality of Education In Tanzania: An Exploration Into Its Determinants. Journal of Education, Humanities and Sciences, 1, 1-15.

29. Martin, A. J., \& Steinbeck, K. (2017). The role of puberty in students' academic motivation and achievement. Learning and Individual Differences, 53, 37-46.

30. Martínez-Martí, M. L., \& Willibald, R. (2017). Character strengths predict resilience over and above positive affect, self-efficacy, optimism, social support, self-esteem, and life satisfaction. The Journal of Positive Psychology, 12(2), $110-119$.

31. Miller, A. D., Ramirez, E. M., \& Murdock, T. B. (2017). The influence of teachers' self-efficacy on perceptions: Perceived teacher competence and respect and student effort and achievement. Teaching and Teacher Education, 64, 260-269.

32. Muris, P. (2001). A brief questionnaire for measuring self-efficacy in youths. Journal of Psychopathology and Behavioral Assessment, 23(3), 145-149.

33. Moksnes, U. K., Løhre, A., Lillefjell, M., Byrne, D. G., \& Haugan, G. (2014). The association between school stress, life satisfaction and depressive symptoms in adolescents: Life satisfaction as a potential mediator. Social Indicators Research, 125(1), 339-357.

34. Oga-Baldwin, W. L. Q., \& Nakata, Y. (2017). Engagement, gender, and motivation: A predictive model for Japanese young language learners. System, 65, 151-163.

35. Olenik-Shemesh Department of Psychology and Education, Open University of Israel, Ra'anana, Israel, D., \& Heiman Department of Psychology and Education, Open University of Israel, Ra'anana, Israel, T. (2017). Cyberbullying Victimization in Adolescents as Related to Body Esteem, Social Support, and Social Self-Efficacy. The Journal of Genetic Pszchologz, 178(1), 28-43.

36. Perry, R. P. (1991). Perceived control in college students: Implications for instruction in higher education. U: J. C. Smart (Ur.), Higher education: Handbook of theory and research (str. 1-56). New York: Agathon.

37. Ragnarsdottir, L. D., Kristjansson, A. L., Thorisdottir, I. E., Allegrante, J. P., Valdimarsdottir, H., Gestsdottir, S., et al. (2017). Cumulative risk over the early life course and its relation to academic achievement in childhood and early adolescence. Preventive Medicine, 96, 36-41.

38. Raufelder, D., Bakadorova, O., Yalcin, S., Dibek, M. I., \& Yavuz, H. C. (2017). Motivational relations with peers and teachers among German and Turkish adolescents: A cross-cultural perspective. Learning and Individual Differences, 55, $13-20$.

39. Savage, M. W. \& Tokunaga, R. S. (2017). Moving toward a theory: Testing an integrated model of cyberbullying perpetration, aggression, social skills, and Internet self-efficacy. Computers in Human Behavior 71, 353-361.

40. Salmela-Aro, K., \& Upadyaya University of Jyväskylä, K. (2017). Co-Development of Educational Aspirations and Academic Burnout from Adolescence to Adulthood in Finland. Research in Human Development, 14(2), 106-121.

41.Sammons, P., Davies, S., Day, C., \& Gu, Q. (2014). Using mixed methods to investigate school improvement and the role of leadership. Journal of Educational Administration, 52, 565-589.

42. Steinhoff University of Zurich, A., \& Buchmann University of Zurich, M. (2017). Co-Development of Academic Interest and Effortful Engagement and Its 
Role for Educational Attainment in a Tracked School System. Research in Human Development, 14(2), 122-142.

43. Tan Department of Pediatrics, University of South Florida Morsani College of Medicine, St. Petersburg, FL, USA, S. Y., Bradley-Klug Department of Educational and Psychological Studies, University of South Florida, Tampa, FL, USA, K., \& Chenneville Department of Psychology, University of South Florida St. Petersburg, St. Petersburg, FL, USA, T. (2017). Health-related quality of life and mental health indicators in adolescents with HIV compared to a community sample in the Southeastern US. Psychological and Socio-medical Aspects of AIDS/HIV, 29(2), 214-222.

44.Terada, M., \& Kawamoto, T. (2017). Rejection Sensitivity, Self-Efficacy, and Learning Strategy: Mediating and Moderating the Role of Basic Needs Satisfaction. Psychology, 8, 449-462.

45.Williams, G. C. \& Deci, E. L. (1996). Internalization of biopsychosocial values by medical students: A test of self-determination theory. Journal of Personality and Social Psychology, 70(4), 767-779.

46. Wilkerson, K., Pérusse, R., \& Hughes, A. (2013). Comprehensive school counseling programs and student achievement outcomes: A comparative analysis of RAMP versus non-RAMP schools. Professional School Counseling, 16, 172-184.

Мирољуб Ивановић

Угљеша Ивановић

\section{АКАДЕМСКЕ И СОЦИЈАЛНЕ ВАРИЈАБЛЕ КАО ПРЕДИКТОРИ ЗАДОВОљСТВА ШКОЛОМ КОД ПРЕДАДОЛЕСЦЕНАТА}

Сажетак: Предмет већине досадашьих студија у психологији образовања, поред сазнајних аспеката учења и школског успеха ученика, фокусиран је и на емоционална и сочијална искуства предадолесцената, као и ғихову периепцију школе. Циљ овог истраживања био је испитивање предиктивног доприноса академских и соиијалних фактора (соиијалне самоефикасности, периипиране академске контроле, соиијалне интегрисаности и периепиије наставничке подршке) у објашњењу задовољства школом код ученика у раној адолесцениији. Истраживање је обухватило пригодан узорак од 230 испитаника, 120 женског пола и 110 мушког пола из Ваљева, узраста 14,52 1,38 година. Примењени су мерни инструменти: Скала периипиране академске контроле (РАC), Упитник самоуспешности за децу (SEQ-C), Упитник наставничког подржавања аутономије (LCQ) и Упитник квалитета школског живота $(Q C L)$, који су показали задовољавајућу интерну конзистенициу. Добијени резултати непараметријског Пирсоновог коефииијента корелације показали су да постоји статистички значајна, ниска и умерена, позитивна повезаност између скорова на скали и упитника PAC, SEQ-C, LCQ и QCL ( $p$ < 0.01). Резултати хијерархијских регресијских анализа сугеришу да академске и соиијалне варијабле објашьавају $61 \%$ укупне варијансе критеријума, а као 
самостални статистички значајни предиктори општег задовољства школом издвојили су се наставничка подрика ученицима, социјална интегрисаност, перциипирана академска контрола, сочијална самоуспешност и школски успех ученика. То указује да предадолесценти с вишим резултатима на тим варијаблама постижу и више скорове на мери задовољства школом. Такође, у раду су размотрене практичне и теоријске импликащије добијених резултата за стварање подстицајног школског окружења у раном адолесиентном периоду. Добијени налази ученичких уверена о својим особинама могу бити врло корисни за дијагностификовање и планирање академских и сочијалних детерминанти, које позитивно доприносе ученичком општем задовољству школом и реализацији наставних и ваннаставних активности.

Кључне речи: самоуспешност, академска контрола, школски живот, подрика наставника, задовољство иколом.

Примљено: 14. 2. 2018. године.

Одобрено за штампу: 14. 5. 2018. године. 